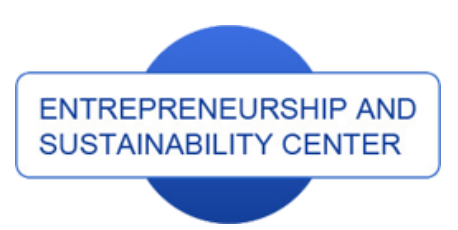

Publisher

http://jssidoi.org/esc/home enterprise

europe

network

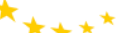

Business Support on Your Doorstep

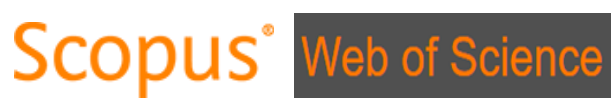

1) Clarivate

\title{
IMPROVING THE SYSTEM OF LABOR INCENTIVES AND STIMULATION IN OIL COMPANIES
}

\author{
Vera Vladimirovna Plenkina ${ }^{1}$, Irina Vladimirovna Osinovskaya ${ }^{2}$ \\ ${ }^{1,2}$ Tyumen Industrial University, Volodarskogo Street 38, 625000, Tyumen, Russia \\ E-mails: ${ }^{1}$ plenkinavv@tyuiu.ru ${ }^{2}$ osinovskaya79@mail.ru
}

Received 10 June 2018; accepted 26 November 2018; published 30 December 2018

\begin{abstract}
The article addresses the issues related to improving the efficiency of the incentives' system at the level of oil-producing structures through the improvement of its financial component. It refers to improving the grading system, which is a fairly semipolar remuneration plan in oil companies. The problem of reaching the maximum wage level for employees in the grading system and reducing its incentive function has been considered in its entirety. The development of an efficient, transparent system of personnel incentives is a relevant problem for many companies. The paper reveals the causes of this problem and possible ways to solve it, and also considers the technology of the grading system formation at an oil-producing enterprise. Expansion of grade levels is one of the priority areas for improving the grading system. The pay range is justified with the purpose of ensuring a competitive pay level for different groups of positions. The need for regrading - the revision of the system of ten-tier wage structure of grades to a larger scale, with a large number of pay ranges - is confirmed by the estimated efficiency of the measure. Besides, the paper considers the expediency of shifting oil field employees to grading system payments.
\end{abstract}

Keywords: incentives; grade; oil company; method; regrading; personnel

Reference to this paper should be made as follows: Plenkina, V.V. Osinovskaya, I.V. 2018. Improving the system of labor incentives and stimulation in oil companies, Entrepreneurship and Sustainability Issues 6(2): 912-926. http://doi.org/10.9770/jesi.2018.6.2(29)

JEL Classifications: M5, M54

\section{Introduction}

In the context of a complicated economic position of the country without labor incentives, high discipline and good organization, the enterprises find it difficult to operate efficiently. According to Korsik A.L., President of one of the Russian oil companies, the competition in the existing market assumes that companies benefit not from technology and techniques, but rather from people, their knowledge and enthusiasm. People today are the key competitive advantage (Annual Report of JSC JSOC Bashneft 2012). The decisive factor in people's performance is their motivation. 


\section{The International Journal}

ENTREPRENEURSHIP AND SUSTAINABILITY ISSUES

ISSN 2345-0282 (online) http://jssidoi.org/jesi/

2018 Volume 8 Number 2 (December)

http://doi.org/10.9770/jesi.2018.8.2(29)

Despite the fact that the pay level at oil-producing enterprises is somewhat higher than in other industries, certain difficulties arise in the development of a system of labor incentives and stimulation. There are situations of reaching the maximum wage level in a certain category of employees and the lack of viewing further progress toward higher pay levels within the current system of incentives. A grading system is the most common pay system at oil companies.

The official documents of oil companies state that a grade is a group of positions with approximately similar values for the company. Each grade corresponds to a certain salary, or "salary brackets," which can be reviewed from time to time, though the grading system remains unchanged. The practice of using the grading system at oil companies has also unveiled some problems, primarily with the definition of the so-called "salary brackets". Insufficient elaboration of the grading system at the company can act not as an incentives' mechanism for an employee, but, on the contrary, as a deterrent to obtaining a high synergetic effect from the implemented system of incentives.

The relevance of the topic is due to the need to address a number of problems in the use of the grading system in the system of labor incentives and stimulation for employees at industry-specific enterprises, where wages are higher than at enterprises in other industries.

\section{Literature review}

There is a heightened interest from both representatives of academic science and representatives of the business environment to the solution of the problem of improving the incentives' system efficiency at the moment. The general issues of the formation of a system of labor incentives and stimulation are widely discussed by array of authors (e.g. Kibanov et al. 2010; Chekmarev 2013; Pink 2012; Spivak 2013; Scheer 2012; Huselid et al. 2007; Borisov et al. 2018). Various aspects, specifically, of the grading system formation are disclosed in the papers of Konyukova N.I., Artamonov B.V., Stepanenko E.V., Vereshchagina L.S., Slipachuk S., Stepanov M.V. and others (Konyukova 2013; Artamonov and Stepanenko 2015; Vereshchagina 2016; Slipachuk 2010; Stepanova 2012). Practical implementation of the grading system is covered in the annual reports of industry oil companies, as well as in the publications of representatives of the business environment, managers of various levels - for example, articles by Saifieva G., Zhvakin A. (Saifieva 2008; Zhvakin 2013) are dedicated to this issue.

\section{Materials and methods}

\subsection{Information and methodological support of evaluating the efficiency of the system of labor incentives and stimulation}

The payroll management in large oil companies is a difficult problem; besides, an unfair and/or "non-transparent" remuneration plan can significantly reduce the productivity of employees (Plenkina et al. 2018). Therefore, the development of an efficient, transparent system of personnel incentives is an acute problem for many companies. Economists offer numerous methods for developing corporate remuneration plans, but the grading system remains one of the most popular. The most well-known grading systems were offered by Watson Wyatt and Hay Group, but other options were also used. The grading (position posts) system is a kind of corporate "table of ranks", where each position grade corresponds to its pay level. Grading is a method of creating a universal hierarchy of positions (ranks) for all the company's personnel; an evaluation system that allows to determine reasonable levels of remuneration for all employees based on comparison of relative value of different parts of work (positions) for the company. The main advantage of grading is "measuring the immeasurable" - translating an intangible indicator, such as "the value of an employee's work", into a monetary equivalent (Mesropyan et al. 2016). The main objectives of grading are the following ones: 
- to find the objective value of each employee of a large oil company in each business segment;

- to increase the transparency of the potential career growth in the company for each employee;

- to increase the efficiency of the payroll usage;

- to qualitatively assess the potential of the company's personnel; and

- to attract the attention of potential candidates in the labor market.

Grading allows to systematize all the positions in the company, set the upper and lower pay limits for each level (grade) and create a tool for payroll accounting. After grading, each employee can see the relationship between their work and the company's revenues.

This system enables the employee of the company to:

- realize the place their position has in the existing career hierarchy and assess its role for the company;

- receive fair remuneration for work - depending on the level of complexity, responsibility of the work performed, etc.;

- assess the prospects for their professional and career growth;

- get the opportunity for "flat" career development (advancement in the levels of mastery within one position through more complicated tasks, expanding the range of responsibilities and authorities) - changing the grade or subgrade and the relevant pay level; and

- consistently acquire new professional knowledge and skills necessary for efficient work on a higher position (Lavrov 2008).

After shifting to the grading system, large companies need to adjust it from time to time and constantly monitor its functionality. Over time, the grading system loses its functionality and does not allow achieving the previously set goals and act as an incentive. The company is experiencing a regrading stage. At this stage, the expected effect of the grading system development and the goals of the regrading project are specified. The company must determine its needs: to optimize the payroll costs, to "equalize" the pay for similar positions in different company divisions, to indicate "key" posts and develop a policy of attracting and retaining the best specialists, to audit the pay level in the company and to adjust it in accordance with the market realities.

Tasks that can be set by an operating oil producing enterprise that implements a grading system in its practice, are the following:

- ranging the career hierarchy;

- determining the value of all positions in the company and the pay range ("brackets") for each group of positions; and

- optimizing the organizational structure and staffing.

The company's social policy, incentives' programs and career development programs are also developed based on the grading system (employees are aware of the change in income levels in case of various career movements). The main thing is that the company can choose the right people for key activities and reasonably pay better money to its best employees.

Both the introduction of the grading system and regrading are carried out in several stages. At these stages, the information is collected necessary for creating the basic wage structure:

- position analysis - provides key information about the nature and level of the work performed;

- position documentation - reflects the written information about the position content and its functions, as well as the necessary knowledge and skills. The position analysis and documentation provide the information necessary to complete the process of evaluating the position. The process of evaluating the position and building the career hierarchy provide the information necessary to build the wage structure. Evaluation of the position allows to obtain the data necessary to build the career hierarchy. Two main approaches are used: based on the market data and based on the position content.

The stages of introducing the grading system and regrading are presented in Figure 1. 

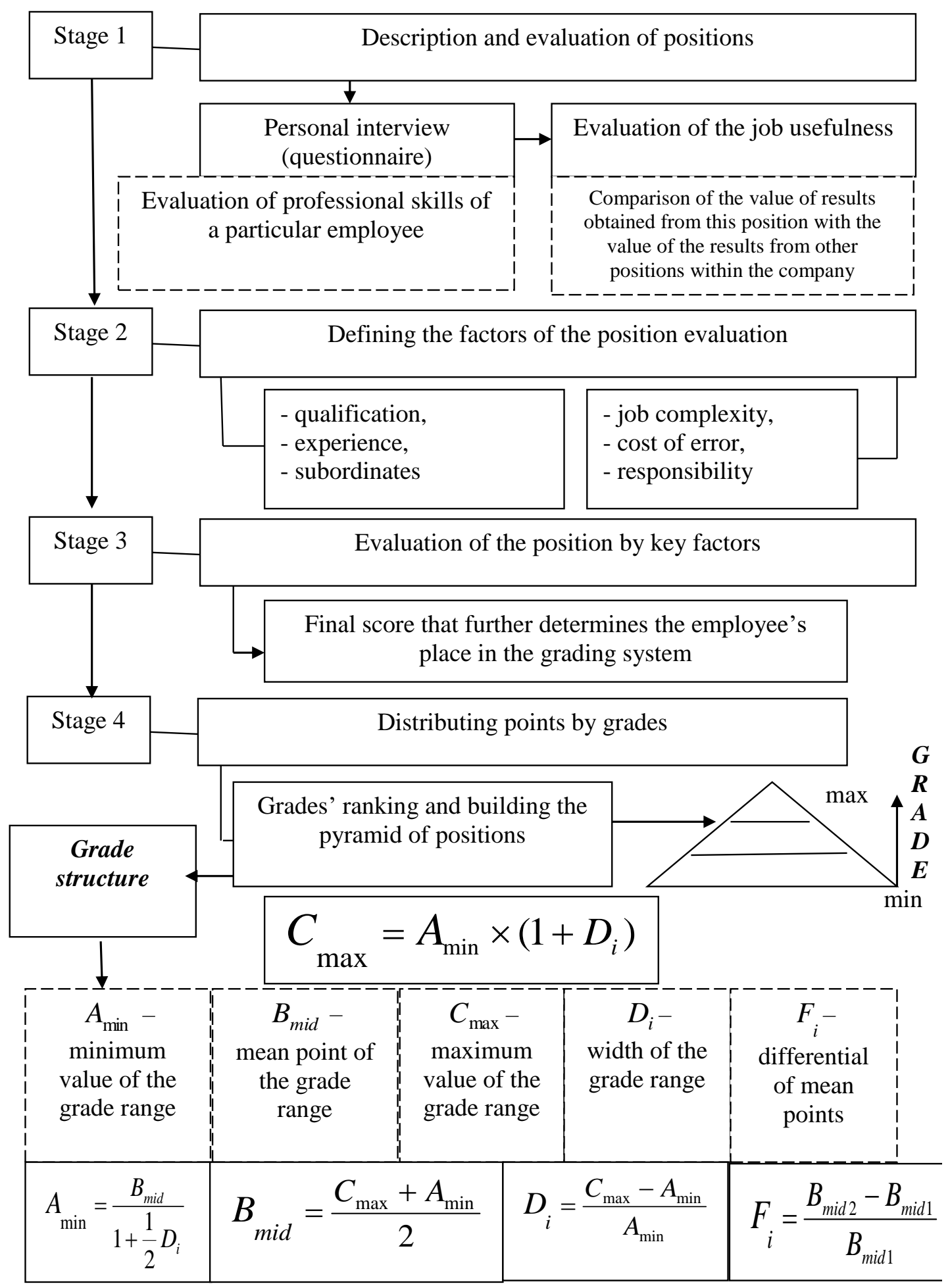

Fig. 1. Stages of introducing the grading system 
The International Journal

ENTREPRENEURSHIP AND SUSTAINABILITY ISSUES

ISSN 2345-0282 (online) http://jssidoi.org/jesi/

2018 Volume 8 Number 2 (December)

http://doi.org/10.9770/jesi.2018.8.2(29)

Evaluation of positions is a systemic approach expressed as a process of determining and comparing the relative value of one position in relation to others. The result of position evaluation is the creation of a career hierarchy in the organization (Tsymbalyuk 2011).

Oil and gas production enterprises use grade-factor method of evaluation based on assigning a certain score to each position in the company. This score reflects the importance of the position for the company. The score assigned to each position determines the remuneration for this position. Internal objectivity is a priority when using the grade-factor approach.

Position grades are formed here on the basis of specific data of grade-factor analysis. The method is based on the evaluation of positions - in other words, on their intrinsic value. The integrated approach is based on the use of the position evaluation system adopted in the organization with the addition of a market component. The key factors are used to form a final score at the stage of position evaluation, which subsequently determines the employee's place in the grading system. It is determined by multiplying the score obtained during the assessment by points of significance of these factors. Points of significance depend on the importance of the position for the company.

The next stage is the points' distribution by grades. All positions are put into a hierarchical pyramid following calculations, depending on the final score. Then this pyramid is divided into grades by obtaining approximately equal number of points, based on the functions performed and depending on the degree of significance of this position for the enterprise. After the grades' formation, the "bracket" ranges of the base wage are set for the positions included in each grade. The enterprises are often guided by the market wage values when setting the "brackets" for wages in each grade. In this case, the lowest and highest wages in the grade can be set, respectively, 15\% lower and 30\% higher than the average market value (Tsymbalyuk 2011).

In its turn, each grade has an internal structure, also shown in Figure 1.

The wage range is set with the purpose of offering competitive wage levels for groups of positions (Chemekov 2010). The wage range includes maximum wage, average (or central) value and minimum wage. Usually, there is a maximum wage level for each position, both in the external market and inside the company. This is why it is very important to monitor the market fluctuations and the market salary fluctuations. For example, if an employee receives the maximum wage in their range, this means that this employee will not get a raise until the range adjustment or until the employee acquires new skills or gains promotion.

The middle of the range (mean point), or the average wage for the range, usually corresponds to a competitive market salary for a given position or a group of positions. It is determined based on the assessment of the current market salary and is often called the payroll policy line. This line shows the pay level in the organization in comparison with the market level.

Usually, there is also a minimum wage level for each position. The minimum wage level is the wage, which is estimated to represent the lowest level of pay for a given position possible in the market or in the organization. It is important not to forget about the minimum range of the employees whose wages are close to this minimum. The range width is the distance from its minimum to the maximum. It is necessary to approach the range width establishment with all responsibility. Suppose that the mean point of the range is constant, but if the width is changed, then the minimum and maximum of the wage range will also change. Table 1 provides examples of wage ranges corresponding to organizational levels, and Figure 2 shows an example of the grade range width. 
Table 1. Examples of wage ranges corresponding to organizational levels

\begin{tabular}{|l|c|}
\hline \multicolumn{1}{|c|}{ Positions } & Range width \\
\hline Services, production and technical support & $20 \%$ to $30 \%$ \\
\hline Secretaries, technical and administrative personnel & $30 \%$ to $40 \%$ \\
\hline Specialists and supervisors & $40 \%$ to 50\% \\
\hline Managers and executives & $50 \%$ and more under certain circumstances \\
\hline
\end{tabular}

Figure 2 shows the components of the grade range.

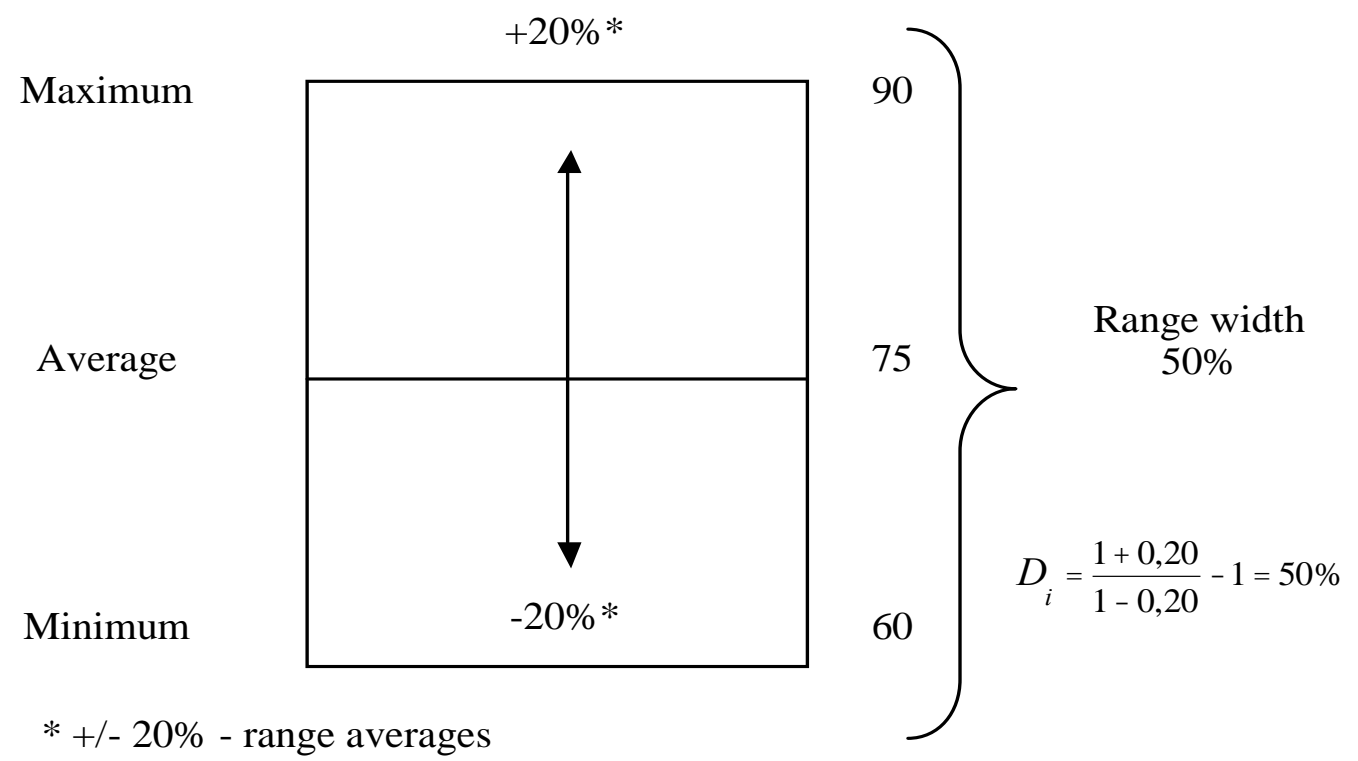

Fig. 2. Grade range width

The grade range width is calculated in two ways:

1) Width from minimum to maximum:

$$
D_{i}=\frac{C_{\max }-A_{\min }}{A_{\min }}
$$

2) Width is calculated as the distance from the average up and down:

$$
L_{i \downarrow}=\frac{A_{\text {min }}-B_{\text {mid }}}{B_{\text {mid }}} \text { or } \quad L_{i \uparrow}=\frac{C_{\text {max }}-B_{\text {mid }}}{B_{\text {mid }}}
$$


The following formulas are used to translate the distance from the average to the distance from minimum to maximum:

$$
D_{i}=\frac{1+\% L_{i \uparrow}}{1-\% L_{i \downarrow}}-1
$$

Differential of mean points is the difference between the salaries corresponding to the mean values of the two adjacent grades.

The following main factors taken into account in calculation are worth noting:

- level of detail of the position evaluation method does not provide for detailed differences between levels, which results in fewer levels;

- market competitiveness (market salaries from the lowest to the highest position in the structure). In this case, the mean points should be coordinated with the adopted salary policy line; and

- cost of career promotion. The percentage difference between the mean points should be consistent with the promotion policy adopted in the organization. For example, if the promotion policy limits the wage raise in promotion to $8 \%$, and the differential of mean points is $15 \%$, the salaries of some employees after the promotion may appear below the minimum of their main job grade.

The following formula is used to find the differential of mean points for adjacent grades:

$$
F_{i}=\frac{B_{m i d 2}-B_{m i d 1}}{B_{m i d 1}}
$$

Ranges may overlap during the formation of a grading system, which will allow to move along the wage structure (within grades and ranges) due to efficient work, promotion, demotion, change of the position class, market adjustments, etc.

As a rule, the ranges overlap largely due to the philosophy of the organization and the position evaluation system. There are more significant overlaps if a grade-factor system is used. The ranges will not overlap much if the market information-based approach is applied, which will allow to routinely change the ranges. Usually, there are very small ranges' overlaps in organizations for executive grades due to unique positions. However, some overlap is acceptable due to the talent pool planning. Ranges' overlapping is also important for internal promotions. Problems may arise if there are significant overlaps in the structure.

Some organizations use the method of consolidation of wage categories, which leads to the adoption of a wage structure, where a large number of wage grades and salary ranges are combined into a smaller number of categories with relatively wide salary ranges. The typical difference between the minimum and maximum in the consolidated categories is $100 \%$ or more.

\subsection{Developing a set of measures to improve the efficiency of the labor incentives and stimulation system based on the grading system}

One of the relevant problems existing at the level of oil and gas producing structures is the discrepancy between the current employee incentives' system consisting of a 10-tier wage structure of grades and the scale of the oil and gas producing enterprise. The research of various positions revealed that the adopted grading system lacks sufficient incentives to increase the efficiency of the specialists' work because their wages are the highest within the limits of a certain grade. 
In other words, the grading system adopted at such enterprises does not actually achieve the goals of grading:

- to establish the objective value of each employee for the company;

- to increase transparency of career prospects for employees; and

- to conduct qualitative assessment of personnel.

This is why regrading is required - a revision of the system of 10-tier wage structure of grades to a larger scale, with a large number of wage ranges.

Besides, it is proposed to shift the field workers, whose job was previously remunerated in accordance with salaries and hourly tariff rates approved by the personnel chart, to the grading system. This measure is determined by the necessity to switch the entire enterprise to the uniform grading system with the purpose to allow each employee to clearly understand what level of hierarchy in the company their position belongs to and why. Besides, if such a system is introduced, the company excludes the chance of subjectivity in remuneration - a request from employees who simply ask the management to raise wages for some important (in their opinion) reasons.

A grade-factor approach was used to switch to a 21-tier wage structure, where the following steps were taken:

- checking the differentials of the final score values by groups of related positions;

- ranking positions from high to low;

- grouping positions based on logic, i.e. logical groups of positions based on their values were specified;

- building score categories (on the basis of absolute or percentage values), in this case they were built with some pattern in the range width; and

- checking the relationship within related groups and the relationship between the positions of the supervisor/subordinate.

The following criteria were used for position evaluation:

- knowledge and skills, which include the degree of special knowledge and skills, breadth of management, communication skills;

- problem resolution (scope of problems to be solved, complexity of problems to be solved (evaluation), complexity of problems to be solved (\%); and

- responsibility (freedom of action (authority), importance (magnitude) of impact, type of influence).

\section{Results}

Approbation of the presented method resulted in the final structure of the proposed 21-tier system of grades, which looked as follows (Table 2): 
Table 2. Proposed 21-tier system of grades

\begin{tabular}{|c|c|c|c|c|c|c|}
\hline GRADE & $\begin{array}{c}\text { Grade minimum } \\
\text { value, } \$\end{array}$ & $\begin{array}{c}\text { Grade median, } \\
\$\end{array}$ & $\begin{array}{c}\text { Grade } \\
\text { maximum } \\
\text { value, } \\
\$\end{array}$ & $\begin{array}{l}\text { Differential of } \\
\text { mean points, } \%\end{array}$ & $\begin{array}{l}\text { Grade range } \\
\text { width, \% }\end{array}$ & Hay score \\
\hline 21 & 3,120 & 4,135 & 5,149 & 17 & 65 & 901 and more \\
\hline 20 & 2,713 & 3,528 & 4,342 & 30 & 60 & $805-900$ \\
\hline 19 & 2,125 & 2,710 & 3,294 & 13 & 55 & $634-804$ \\
\hline 18 & 1,915 & 2,393 & 2,872 & 12 & 50 & 519-633 \\
\hline 17 & 1,710 & 2,137 & 2,564 & 12 & 50 & $451-518$ \\
\hline 16 & 1,554 & 1,904 & 2,253 & 11 & 45 & $393-450$ \\
\hline 15 & 1,400 & 1,715 & 2,030 & 11 & 45 & $333-392$ \\
\hline 14 & 1,284 & 1,541 & 1,798 & 9 & 40 & $282-332$ \\
\hline 13 & 1,177 & 1,414 & 1,650 & 9 & 40 & $252-281$ \\
\hline 12 & 1,101 & 1,294 & 1,487 & 9 & 35 & $199-251$ \\
\hline 11 & 1,029 & 1,184 & 1,338 & 7 & 30 & 175-198 \\
\hline 10 & 962 & 1,106 & 1,251 & 5 & 30 & $160-174$ \\
\hline 9 & 916 & 1,054 & 1,191 & 4 & 30 & 140-159 \\
\hline 8 & 881 & 1,013 & 1,145 & 10 & 30 & 120-139 \\
\hline 7 & 799 & 919 & 1,039 & 3 & 30 & $110-119$ \\
\hline 6 & 776 & 892 & 1,008 & 2 & 30 & \multirow{6}{*}{ less than 109} \\
\hline 5 & 761 & 875 & 989 & 2 & 30 & \\
\hline 4 & 746 & 857 & 969 & 2 & 30 & \\
\hline 3 & 731 & 841 & 950 & 2 & 30 & \\
\hline 2 & 717 & 824 & 932 & 2 & 30 & \\
\hline 1 & 703 & 808 & 913 & & 30 & \\
\hline
\end{tabular}

Table 3 shows the distribution of positions (based on the evaluation results) in accordance with the new 21-tier system of grades

Table 3. Distribution of positions in the 21-tier system of grades following the evaluation results

\begin{tabular}{|c|l|l|}
\hline Grade & \multicolumn{1}{|c|}{$\begin{array}{c}\text { Positions of the office employees at the } \\
\text { enterprise }\end{array}$} & \multicolumn{1}{c|}{ Positions of the oilfield workers at the enterprise } \\
\hline 21 & Director General & Head of oilfield \\
\hline 20 & Deputy Director General & - \\
\hline 19 & Heads of bureaus & $\begin{array}{l}\text { Heads (of workshops, plots, oil acceptance station, chemical } \\
\text { analysis laboratory, etc.) }\end{array}$ \\
\hline 18 & Heads of departments & $\begin{array}{l}\text { Chief specialists (for construction supervision, labor protection } \\
\text { and occupational safety, etc.) }\end{array}$ \\
\hline 17 & Chief specialists & \\
\hline 16 & & \\
\hline
\end{tabular}




\begin{tabular}{|c|l|l|}
\hline 14 & Senior (specialists, engineers) & $\begin{array}{l}\text { Senior (engineers, specialists, geologists, land surveyors, } \\
\text { technologists, etc.) } \\
\text { Lead (mechanics, foremen, etc.) }\end{array}$ \\
\hline 12 & $\begin{array}{l}\text { Specialists (engineers, assistants of the director } \\
\text { general and the chief engineer) }\end{array}$ & $\begin{array}{l}\text { Engineers (maintenance and test, pre-production, occupational } \\
\text { safety, etc.) } \\
\text { Operators, mechanics, technologists, etc. }\end{array}$ \\
\hline 11 & & $\begin{array}{l}\text { Occupations of the 6th category (operators for oil and gas } \\
\text { extraction, equipment mechanics, motorists, WO operations } \\
\text { drillers, etc.) }\end{array}$ \\
\cline { 3 - 3 } & & $\begin{array}{l}\text { Occupations of the 5th category (bulldozer drivers, operators } \\
\text { of refueling stations, etc.) }\end{array}$ \\
\cline { 1 - 1 } & & $\begin{array}{l}\text { Occupations of the 4th category (gas equipment maintenance } \\
\text { and repair locksmiths, pipeline walkers, etc.) }\end{array}$ \\
\hline 10 & - & $\begin{array}{l}\text { Occupations of the 3rd category (process pump operators, } \\
\text { loading operators, etc.) }\end{array}$ \\
\hline 8 & - & Drivers, progressmen \\
\hline 7 & - & \\
\hline $6-1$ & - & \\
\hline
\end{tabular}

The above tables allow to track the expected changes in the pay of the positions under review:

- Director General - this position corresponded to the 10th grade and had almost the maximum value in this grade range. In the new 21-tier system of grades, the position of Director General falls within the 21 st grade range. The estimated monthly income is $\$ 3,788$. The range of the 21 st grade has the minimum value of $\$ 3,121$ and the maximum value of $\$ 5,149$. Thus, the incentives are clearly seen for improving the performance of the director general. In other words, the salary has a room to grow (within the relevant grade range);

- heads of departments - 7th grade. Again, the estimated monthly income is at the maximum of the grade range. Under the new system, this position corresponds to the 17th and 18th grades with a range of values from $\$ 1,710$ to $\$ 2,872$. The estimated monthly income of the head of department is $\$ 1,995$, which also assumes a room for growth. Besides, there are different departments at the enterprise. It is no surprise that the salary of the Documentation Management Department Head and the Production Department Head, whose positions correspond to one grade, differ in their values in accordance with the importance of their units for the enterprise and labor contribution.The same picture (in Table 4 and Table 5) can be seen by the example of other positions. As such, with the widening of the range of grade values, the incentives for employees to increase labor efficiency grow accordingly.

Table 4. Distribution of positions in the 21-tier system of grades for the office employees at the enterprise

\begin{tabular}{|c|c|c|c|c|c|c|c|c|}
\hline \multirow{3}{*}{$\begin{array}{l}\text { Positions of the } \\
\text { office employees }\end{array}$} & Salary, \$ & \multirow{3}{*}{$\begin{array}{c}\text { Estimated } \\
\text { monthly } \\
\text { income of } \\
\text { office } \\
\text { employees, \$ }\end{array}$} & \multirow{3}{*}{$\begin{array}{c}\text { Gra } \\
\text { de }\end{array}$} & \multirow{3}{*}{$\min$} & \multirow{3}{*}{ mid } & \multirow{3}{*}{$\max$} & \multirow{3}{*}{$\begin{array}{c}\text { Differen } \\
\text { tial of } \\
\text { mean } \\
\text { points }\end{array}$} & \multirow{3}{*}{$\begin{array}{l}\text { Grade } \\
\text { range } \\
\text { width }\end{array}$} \\
\hline & $\max$ & & & & & & & \\
\hline & $\min$ & & & & & & & \\
\hline Director General & 2,635 & 3,788 & 21 & 3121 & 4,135 & 5149 & $17 \%$ & $65 \%$ \\
\hline \multirow{2}{*}{$\begin{array}{l}\text { Deputy Director } \\
\text { General }\end{array}$} & 1,932 & 2,778 & \multirow{2}{*}{20} & \multirow{2}{*}{2714} & \multirow{2}{*}{3,528} & \multirow{2}{*}{4342} & \multirow{2}{*}{$30 \%$} & \multirow{2}{*}{$60 \%$} \\
\hline & 1,897 & 2,727 & & & & & & \\
\hline \multirow{2}{*}{ Heads of bureaus } & 1,528 & 2,197 & \multirow{2}{*}{19} & \multirow{2}{*}{2125} & \multirow{2}{*}{2,710} & \multirow{2}{*}{3294} & \multirow{2}{*}{$13 \%$} & \multirow{2}{*}{$55 \%$} \\
\hline & 1,484 & 2,134 & & & & & & \\
\hline
\end{tabular}


The International Journal

ENTREPRENEURSHIP AND SUSTAINABILITY ISSUES

ISSN 2345-0282 (online) http://jssidoi.org/jesi/

2018 Volume 8 Number 2 (December)

http://doi.org/10.9770/jesi.2018.8.2(29)

\begin{tabular}{|c|c|c|c|c|c|c|c|c|}
\hline \multirow{2}{*}{$\begin{array}{l}\text { Heads of } \\
\text { departments }\end{array}$} & 1,388 & 1,995 & 18 & 1915 & 2,393 & 2872 & $12 \%$ & $50 \%$ \\
\hline & 1,317 & 1,894 & 17 & 1710 & 2,137 & 2564 & $12 \%$ & $50 \%$ \\
\hline \multirow{2}{*}{ Chief specialists } & 1,300 & 1,794 & 16 & 1554 & 1,904 & 2253 & $11 \%$ & $45 \%$ \\
\hline & 1,142 & 1,576 & 15 & 1400 & 1,715 & 2030 & $11 \%$ & $45 \%$ \\
\hline \multirow{2}{*}{$\begin{array}{l}\text { Senior (specialists, } \\
\text { engineers) }\end{array}$} & 1,054 & 1,454 & 14 & 1284 & 1,541 & 1798 & $9 \%$ & $40 \%$ \\
\hline & 966 & 1,333 & 13 & 1178 & 1,414 & 1650 & $9 \%$ & $40 \%$ \\
\hline \multirow{2}{*}{$\begin{array}{l}\text { Specialists } \\
\text { (engineers, } \\
\text { assistants of the } \\
\text { director general } \\
\text { and the chief } \\
\text { engineer }\end{array}$} & 878 & 1,162 & \multirow[b]{2}{*}{12} & \multirow[b]{2}{*}{1101} & \multirow[b]{2}{*}{1,294} & \multirow[b]{2}{*}{1487} & \multirow[b]{2}{*}{$9 \%$} & \multirow[b]{2}{*}{$35 \%$} \\
\hline & 843 & 1,115 & & & & & & \\
\hline
\end{tabular}

Table 5. Distribution of positions in the 21-tier system of grades for the oilfield workers at the enterprise (fragment of research)

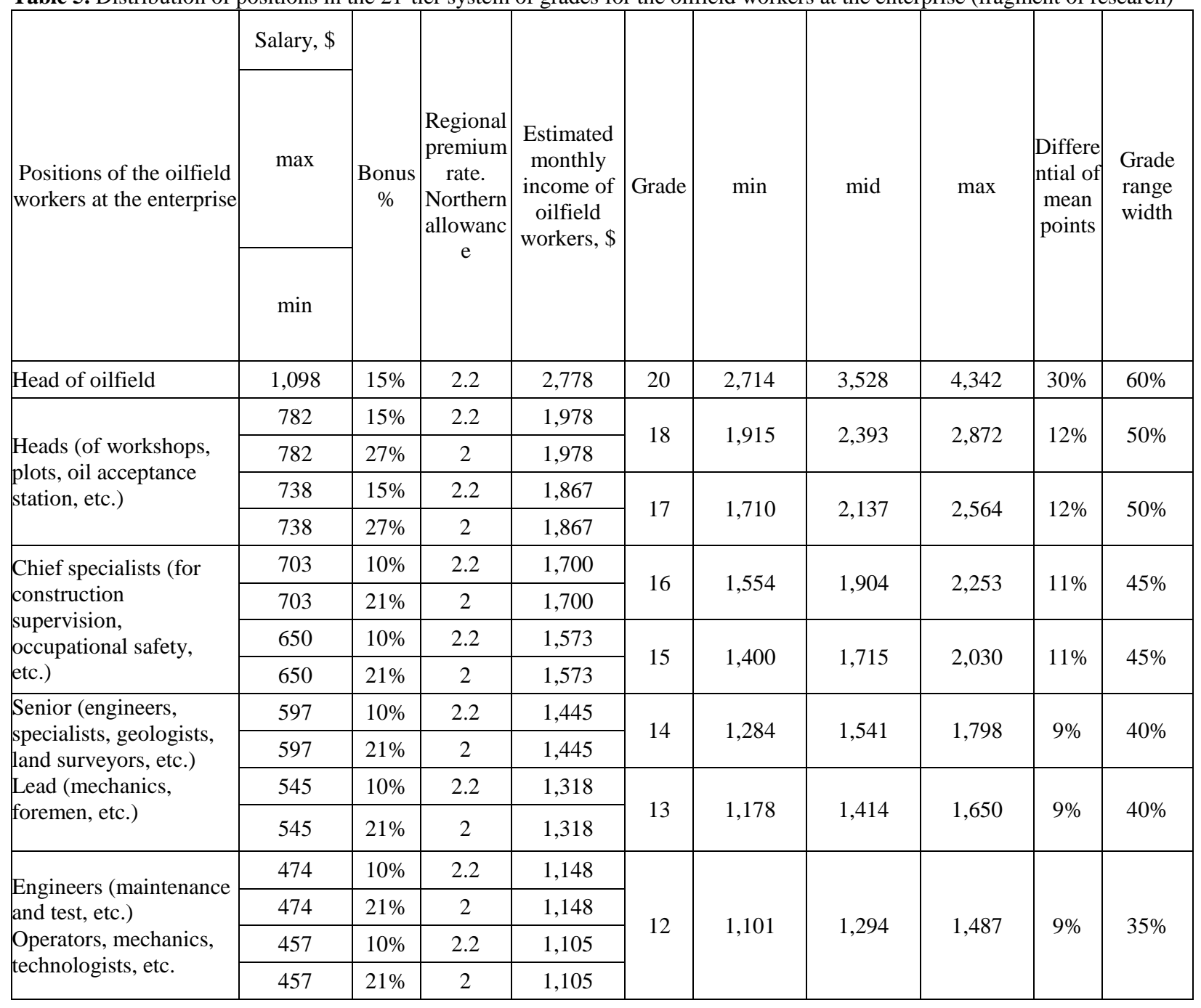


As a result, it can be stated that the oil and gas producing enterprise does not stand still, it develops, and the earlier adopted priorities can be changed. These changes should be reflected in the composition and number of factors of labor evaluation.

\section{Discussion}

So far, the problem of high staff turnover remains relevant for many Russian oil companies, as evidenced by the data of annual reports published on official websites of oil companies. The headcount in the oil and gas sector does not show the required general trend to grow and changes both upwards and downwards. In order to solve the problem of staff turnover, the oil and gas enterprises introduce many programs aimed at personnel motivation and retaining. They also improve the existing incentives' systems from time to time, including the grading system. When considering the established level of average salary in the oil and gas industry in general, it can be concluded that the level is slightly higher than in other industries in Russia, but it is significantly lower than the same in foreign companies. This fact is proved by the results of analytical agencies' research and official research results published in the open press. The Society of Petroleum Engineers annually conducts research on annual salaries in the oil industry. For example, the average salary of oilfield workers in Russia ranges from $\$ 2400$ and more. For example, employees of Gazprom Neft earns \$ 5600-5700 per month and employees of Rosneft - from \$2200. Fairly high salaries of top managers significantly affect the employees' salaries. There are also enterprises where employees receive much less than in the above-mentioned companies. The average salary in Russia in the oil industry is $\$ 2500$. As a comparison, salaries of employees involved in oil and gas production sector in other countries (on the basis of the position salary amount): Norway - \$12700, New Zealand - \$10600, the Netherlands - \$ 10300, the USA - \$ 10100, France - \$ 7700.

In order to maintain the developed remuneration plan based on grades in the relevant state, a regular "upgrade" of the system is required. First of all, the frequency of monitoring is defined: the system adequacy is usually verified once a year: on the one hand, it allows not to get important changes both inside the company and the labor market out of control, and on the other hand, this frequency will not allow to change it beyond recognition.

Adjustments can be either soft or hard. Soft changes in the grading system include changes in the weights of the compensable factors. For example, it used to be important to focus on such factor as "labor content", but the focus may shift after some unification of activities - for example, to "work experience". Hard methods of system adjustment usually refer to the change in the number or content of the factors or the scale of the degree of an individual factor. In this case, all positions and professions have actually been reassessed for new factors, which means almost complete reconsideration of the system. This requires certain resources, both labor and financial.

The Hi-Tech Group is the most well-known company in this field of services, specializing in human resource \& organization development consulting. It is recommended to use its services to solve the regrading tasks at the enterprise in this case.

The advantages and drawbacks of the grading system that arise in the practice of Russian companies are actively discussed in various publications - for example, on the leading HR portal (Tsimbalyuk 2017; Sorokina and Bespalova 2017).

The remuneration plan based on grades has the following advantages:

- it helps manage the wage pool and makes the payroll system flexible;

- it allows to quickly analyze the structure of the wage pool and official salaries and track their dynamics;

- it is a convenient tool for determining the base salary for a new position;

- it allows to define levels and units with inconsistencies in payroll;

- it allows to determine how much a job of any level costs for the company; 
- it is an efficient way to integrate various company departments into a single structure; and

- it optimizes the distribution of labor resources.

\section{Conclusion}

Based on the analysis of the existing incentives' system at the industry-specific enterprise (10-tier wage structure of grades) intended for office employees, it is clear that after the review and switch to the 21-tier grading system, which is uniform for the entire organization, each employee will clearly understand what level of hierarchy in the company their position belongs to and why. Besides, if such a system is introduced, the company excludes the chance of subjectivity in remuneration - a request from employees who simply ask the management to raise wages for some important (in their opinion) reasons.

It makes sense to assume that after the new 21-tier grading system is introduced in all departments of the enterprise, as proposed, the wage fund should be optimized. However, a goal of the reduction in the wage fund is not set when revising the current grading system. At the same time, a detailed analysis of positions will allow not only to evaluate the need for the existence of a specific position, but also to determine its costs, which will result in more efficient planning of personnel costs.

Regrading at an enterprise entails both changes in the labor organizational conditions and improvement of the employees' performance due to an increase in the incentive to work. Aside from the organizational formalities of the grading system in papers, it is required to implement the system in the minds of the personnel, demonstrate all its advantages and to teach heads of departments who have not previously encountered grading to work in this system.

\section{References}

Annual report of JSC JSOC Bashneft. 2012. Retrieved from: http://www.bashneft.ru/disclosure/annual/

Artamonov B. V. and Stepanenko E. V. 2015. Upravleniye chelovecheskimi resursami [Managing human resources]. Moscow: MSTU CA.

Borisov, A.; Narozhnaia, D.; Tarando, E.; Vorontsov, A.; Pruel, N.; Nikiforova, O. 2018. Destructive motivation of personnel: a case study of Russian commercial companies, Entrepreneurship and Sustainability Issues 6(1): 253-267. https://doi.org/10.9770/jesi.2018.6.1(16)

Chemekov V. P. 2010. Greyding: tekhnologiya postroyeniya sistemy upravleniya personalom [Grading: technology of building a personnel management system]. Publishing house Vershina.

Chekmarev O. P. 2013. Motivatsiya i stimulirovaniye truda [Incentives and stimulation of labor]: study guide. Saint-Petersburg.

Huselid M. A., Ulrich D. and Becker B. E. 2007. The HR Scorecard: Linking People, Strategy, and Performance. Moscow: "Williams".

Kibanov A. Ya., Batkayeva I. A., Mitrofanova E. A. and Lovcheva M. V. 2010. Motivatsiya i stimulirovaniye trudovoy deyatelnosti [Incentives and stimulation of labor]: Textbook. Moscow: INFRA-M.

Konyukova N. I. 2013. Oplata truda personala [Remuneration plan]: study guide. SibASS. Novosibirsk: SibASS publishing house.

Lavrov A. M. 2008. S greydom po zhizni [With a grade for life]. HR: electronic manual, 5, 76-83.

Mesropyan M. A., Tsarev V. E. and Vershina D.A. 2016. Protsess vnedreniya sistemy greydov na predpriyatii [The process of introducing a grading system at the enterprise]. Young scientist, 11, 847-849.

Pink D. 2012. Drive: The Surprising Truth about What Motivates Us. New York: Riverhead Books.

Plenkina, V.; Andronova, I.; Deberdieva, E.; Lenkova, O.; Osinovskaya, I. 2018. Specifics of strategic managerial decisions-making in Russian oil companies, Entrepreneurship and Sustainability Issues 5(4): 858-874. https://doi.org/10.9770/jesi.2018.5.4(11) 
The International Journal

ENTREPRENEURSHIP AND SUSTAINABILITY ISSUES

ISSN 2345-0282 (online) http://jssidoi.org/jesi/

2018 Volume 8 Number 2 (December)

http://doi.org/10.9770/jesi.2018.8.2(29)

Saifieva G. 2008. Otsenka po greydu. Sistematizatsiya oplaty truda sotrudnikov (Gazprom neft) [Grading evaluation. Systematization of remuneration plan (Gazprom Neft)]. Retrieved from: http://www.gazprom-neft.ru/press-center/sibneft-online/archive/2008september/1104639/

Scheer A.-W. 2012. Managing Managers. Alpina Business Books.

Slipachuk S. 2010. Sistema greydov: metodika opredeleniya dolzhnostnykh okladov [Grading system: methodology for determining official salaries]. Salary, 8, 15-22.

Sorokina O. S. and Bespalova V. V. 2017. Kak ustanovit "Vilku” okladov [How to define the salary "brackets"]. HR-portal. Retrieved from: http://www.hr-portal.ru/article/kak-ustanovit-vilku-okladov

Spivak V. A. 2013. Upravleniye personalom dlya menedzherov [HR for managers]: study guide. Moscow: Eksmo.

Stepanova M. V. 2012. Innovatsionnyye podkhody k otsenke personala: greyding [Innovative approaches to personnel assessment: grading]. Proceedings of the SIC Sotsiosphera, 24, 56-66.

Tsymbalyuk S. 2011. Greydovaya sistema otsenivaniya dolzhnostey i oplaty truda: metodologiya, metodika, praktika [Grading system of positions and remuneration evaluation: methodology, method, practice]. HR league (community of HR specialists). Retrieved from: http://hrliga.com/index.php?module=profession\&op=view\&id=1317

Tsymbalyuk S. 2017. Greydovaya sistema otsenivaniya dolzhnostey i oplaty truda: metodologiya, praktika [Grading system of positions and remuneration evaluation: methodology, practice]. Retrieved from: http://hrm.ru/grejjdovaja-sistema-ocenivanija-dolzhnostejj-i-oplatytruda-metodologija-metodika-praktika

Vereshchagina L. S. 2016. Upravleniye voznagrazhdeniyem personala [Managing personnel remuneration]. Saratov: Saratov Social and Economic Institute (branch) of Plekhanov RUE.

Zhvakin A. 2013. Khochesh i mozhesh? Prikhodi i delay! [Willing and able? Come and do it!]. Retrieved from: https://www.sibur.ru/presscenter/publications/SIBURKHocheshimozheshPrikhodiidelay/

\section{Information about the authors}

Vera Vladimirovna PLENKINA - Doctor of Economics, Professor, Head of the Management in FES Industries Department of the Institute of Service and Industry Management at the Tyumen Industrial University, Honorary Figure of Russian Higher Education, Academician of the Russian Academy of Natural Sciences, Honored Worker of the Gas Industry. Area of expertise: socioeconomic problems of regional development, establishment of economic and structural policy in the oil and gas sector of the economy, human resourcing of enterprises in the oil and gas sector of the economy, problems of strategic and operational management of enterprises.

https://orcid.org/0000-0002-5717-3987

Irina Vladimirovna OSINOVSKAYA - Candidate of Economic Sciences, Associate Professor of the Department of Energy Complex Management of the Institute of Service and Industry Management at the Tyumen Industrial University, Adviser of the Russian Academy of Natural Sciences.Area of expertise: problems of development and adoption of managerial decisions in various business segments of oil companies, HR problems in large vertically integrated oil companies, methodological aspects of forming an intracorporate system of personnel motivation and training. https://orcid.org/0000-0003-3383-5920 
The International Journal

ENTREPRENEURSHIP AND SUSTAINABILITY ISSUES

ISSN 2345-0282 (online) http://jssidoi.org/jesi/

2018 Volume 8 Number 2 (December)

http://doi.org/10.9770/jesi.2018.8.2(29)

Register for an ORCID ID:

https://orcid.org/register

Copyright (C) 2018 by author(s) and VsI Entrepreneurship and Sustainability Center

This work is licensed under the Creative Commons Attribution International License (CC BY).

http://creativecommons.org/licenses/by/4.0/

(c) (i) Open Access 